\title{
Serum concanavalin-A binding in rheumatoid arthritis*
}

\author{
M. F. R. MARTIN ${ }^{1}$ P. A. DIEPPE $,{ }^{1} \mathrm{H} . \mathrm{E} . \mathrm{JONES},{ }^{1} \mathrm{C} . \mathrm{WARREN},{ }^{2} \mathrm{~J}$. WHICHER,$^{1}$ \\ AND J. KOHN ${ }^{3}$ \\ From the ${ }^{1}$ Departments of Medicine and Chemical Pathology, Bristol Royal Infirmary; ${ }^{2}$ Department of \\ Chemical Pathology, Torbay Hospital, Torbay; and ${ }^{3}$ Department of Biochemistry, University of Surrey
}

SUMMARY A nephelometric assay of concanavalin-A binding of serum acute phase proteins (con-A binding) has been used in cross-sectional and sequential studies of disease activity in rheumatoid arthritis (RA). Con-A binding correlated well with blood viscosity, C-reactive protein, and other individual acute phase reactants in patients with active RA. Twenty-four patients were treated for 6 months with D-penicillamine and assessed clinically and seriologically. Clinical improvement was accompanied by significant falls in both C-reactive protein and con-A binding, although the serological changes did not always occur in parallel in individual patients. The advantages of this simple, cheap assay of acute phase proteins are discussed.

Concanavalin-A (con-A) is a plant lectin isolated from the jack bean (Concanavalus species). It binds specifically $\alpha$-D-glucosyl, $\alpha$-D-mannosyl, and sterically related structures. Polysaccharides containing these residues in the terminal position will cross-react with con-A forming large complexes of low solubility. Binding is specific and of high affinity, and can be measured by any technique applicable to antigenantibody interactions. ${ }^{1}$ The majority of serum acute phase reactant proteins are glycoproteins containing residues which will bind to, and be precipitated by, con-A. It has recently been shown that con-A binding can therefore be used as a means of measuring acute phase proteins in the blood of both man and animals. ${ }^{2}$

Serum acute phase proteins are widely used to assess the activity and prognosis of rheumatoid arthritis. ${ }^{3}$ The sequential changes in serum levels have also been used as a means of assessing treatment responses to second line drugs such as gold and penicillamine. ${ }^{4} \mathrm{C}$-reactive protein (CRP) has been most widely used in this context, though the addition of other acute phase protein measurements might provide a fuller picture of an inflammatory disease. Con-A binding appears to reflect changes in the majority of serum acute phase reactants, although CRP probably makes no contribution to the measurement owing to the fact that it is not a glyco-

* Presented to the Heberden Society, 11 June 1980.

Accepted for publication 24 February 1981.

Correspondence to Dr P. A. Dieppe, Department of Medicine, Bristol Royal Infirmary, Bristol BS2 8HW. protein. CRP and con-A have therefore been measured alongside conventional clinical and serological assessments of disease activity in patients with rheumatoid arthritis (RA) and during treatment of RA with D-penicillamine.

\section{Materials and methods}

Patients with classical or definite rheumatoid arthritis (ARA criteria $1965^{5}$ ) were studied. Con-A binding was measured with a Hyland laser'nephelometer. ${ }^{1}$ Acute phase proteins were measured by the rocket technique of Laurell ${ }^{6}$ using antisera obtained from Seward Laboratories, London. Cross-sectional and sequential studies were carried out.

CROSS-SECTIONAL STUDY

Fifty consecutive patients with RA attending an outpatient clinic had blood taken for estimation of blood viscosity, CRP, and con-A binding irrespective of disease activity or current therapy. The results were analysed to assess their value as measurements of disease activity.

\section{SEQUENTIAL STUDIES}

Ten patients with active rheumatoid disease had weekly measurements of blood viscosity, con-A binding, CRP, haptoglobin, orosomucoid, $\alpha_{1}$-antitrypsin and antichymotrypsin for 6 weeks. Results were graphed individually for each patient to provide an 
estimate of the changes in each parameter and the correlation between them over a 6-week time period.

Twenty-four patients with active rheumatoid disease on a stable antiinflammatory regimen started treatment with D-penicillamine in an initial dose of $125 \mathrm{mg}$ daily, increasing to a maintenance dose of between $250 \mathrm{mg}$ and $500 \mathrm{mg}$ daily (mean $386 \mathrm{mg}$ per day) for 6 months. Clinical assessment included pain (visual analogue scale), Ritchie index, duration of early morning stiffness, and patient/physician opinion of response to therapy. Serological measurements included haemoglobin, blood viscosity, latex titre, IgG and IgM, CRP, and con-A binding. Clinical and serological measurements were made immediately before starting therapy, and $2,4,6$, and 8 months thereafter. Changes in individual measurements before and during therapy were compared by Student's $t$ test, and correlations between different measurements were made by the correlation coefficient.

\section{Results}

CROSS-SECTIONAL STUDIES

Table 1 shows the con-A binding recorded in 100 healthy blood donors compared with that of the 50 patients with rheumatoid arthritis. Con-A binding was significantly higher in patients with rheumatoid arthritis, although the groups were not age or sex matched. The Table also shows the correlations between CRP, con-A, and blood viscosity in rheumatoid arthritis, all of which were statistically significant.
Table 1 Concanavalin- $A$ binding and CRP levels in healthy blood donors and patients with rheumatoid arthritis. Concanavalin- $A$ binding is expressed as a percentage of a reference serum pool containing high levels of glycoproteins

\begin{tabular}{lll}
$\begin{array}{l}\text { Con-A } \\
\text { binding }\end{array}$ & CRP & $\begin{array}{l}\text { Correlation } \\
\text { coefficient }\end{array}$ \\
\hline
\end{tabular}

\begin{tabular}{|c|c|c|c|}
\hline $\begin{array}{l}100 \text { Normal healthy } \\
\text { blood donors } \\
\text { (age 18-65) }\end{array}$ & $\begin{array}{l}\text { Range: } \\
29-63 \% \\
(\text { mean } 48 \% \pm \\
6.7 \% \text { ) }\end{array}$ & $\begin{array}{l}\text { Range: } \\
0-0.01 \mathrm{~g} / \mathrm{l}\end{array}$ & - \\
\hline $\begin{array}{l}50 \text { active sero- } \\
\text { positive rheumatoid } \\
\text { arthritis patients }\end{array}$ & $\begin{array}{l}\text { Range: } \\
44-118 \% \\
(\text { Mean } 71 \% \pm \\
16 \cdot 8 \%)\end{array}$ & $\begin{array}{l}\text { Range: } \\
0.006-0.248 \mathrm{~g} / \mathrm{l} \\
(\text { Mean } 0.073 \pm \\
0.06)\end{array}$ & $\begin{array}{l}r=0.68 \\
p=<0.01\end{array}$ \\
\hline
\end{tabular}

In the 10 patients who had weekly estimations con-A binding was shown to correlate well with a variety of acute phase proteins. In most cases there was very little variation in the measurements over the 6-week period. One individual example is shown in Fig. 1. In this case there was a considerable change in disease activity during the test period, as reflected by the acute phase protein response, all measurements including con-A binding showing a similar type and degree of change.

The 24 patients started on D-penicillamine therapy had a mean age of $56 \cdot 2$ years (range $42-68$ ) and a mean disease duration of $7 \cdot 5$ years (range 1-25 years). There were 15 women and 9 men. Four patients were withdrawn during the 8-month study because of side effects ( 2 rash, 1 thrombocytopenia, 1 proteinuria). Data were inadequate on 2 other patients. The full results were therefore analysed on a total of 18 subjects. Details of the clinical response

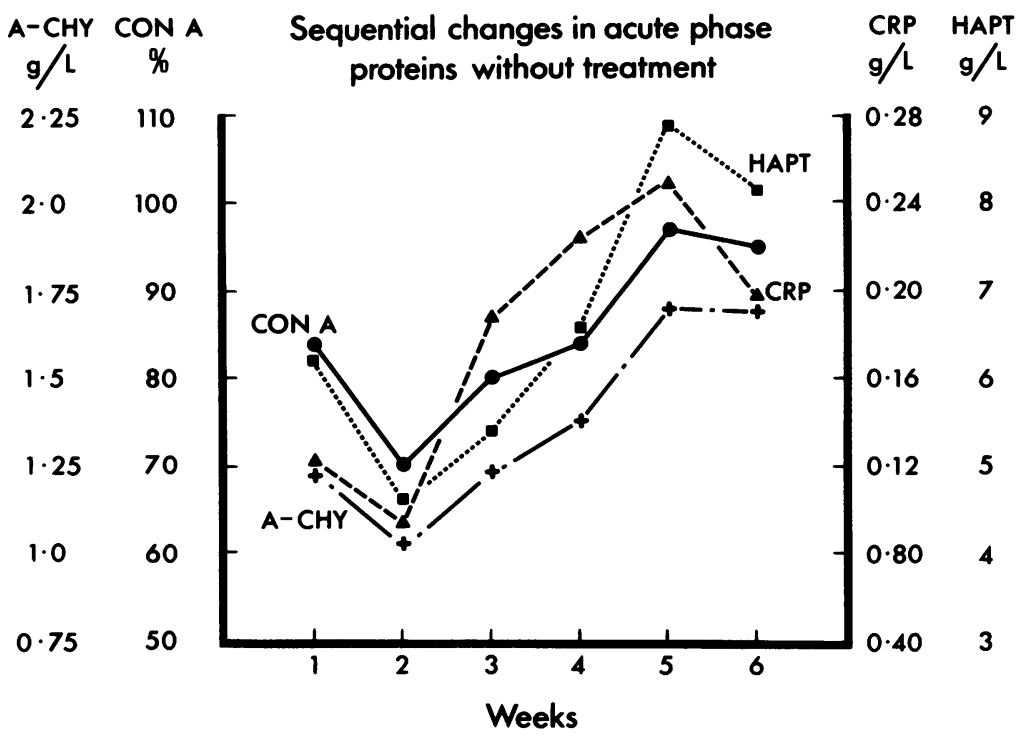

Fig. 1 Acute phase protein changes in 1 patient with rheumatoid arthritis followed up weekly for 6 weeks during an exacerbation of the disease. ( $A-C H Y=$ antichymotrypsin; con- $A=$ concanavalin- $A$ binding; $C R P=C$-reactive protein; $H A P T=$ haptoglobin). 
Table 2 Clinical, haematological, and serological changes in 18 patients treated for 6 months with D-penicillamine: mean $\pm S D$

\begin{tabular}{|c|c|c|}
\hline & \multicolumn{2}{|l|}{ Months } \\
\hline & 0 & 6 \\
\hline Pain (10 cm VAS) & $5.31 \pm 2.6$ & $4.06 \pm 2.9^{*}$ \\
\hline Ritchie articular index & $14.3 \pm 7.9$ & $7 \cdot 90 \pm 8 \cdot 3^{* *}$ \\
\hline Haemoglobin (g/dl) & $10.63 \pm 1.90$ & $12.09 \pm 1.75^{* *}$ \\
\hline Viscosity (cp) & $1.92 \pm 0.24$ & $1 \cdot 76 \pm 0.17^{* * *}$ \\
\hline CRP $(g / 1)$ & $0.059 \pm 0.06$ & $0.032 \pm 0.03^{* *}$ \\
\hline Con-A (\%) & $73.4 \pm 18.3$ & $57.9 \pm 14 \cdot 8^{* * *}$ \\
\hline DAT & 1 in 240 & 1 in $80^{*}$ \\
\hline IgM & $1 \cdot 50 \pm 0.72$ & $1 \cdot 02 \pm 0.50^{* *}$ \\
\hline
\end{tabular}

DAT = differential agglutination titre of rheumatoid factor. ${ }^{*} \mathrm{p}=0.05 . \quad * * \mathrm{p}=<0.02 . \quad * * \mathrm{p}=<0.005$.

Table 3 Correlation coefficients (r) between CRP, plasma viscosity, and concanavalin- $A$ binding before and after 6 months' treatment with $D$-penicillamine (18 patients)

\section{Months}

0

\begin{tabular}{lll} 
Visc: con-A & 0.52 & 0.64 \\
& $p=<0.01$ & $p=<0.01$ \\
Visc: CRP & 0.59 & 0.69 \\
Con-A: CRP & $p=<0.01$ & $p=<0.01$ \\
& 0.62 & 0.31 \\
& $p=<0.01$ & NS \\
\hline
\end{tabular}

NS = not significant.

\section{Sequential acute phase proteins}

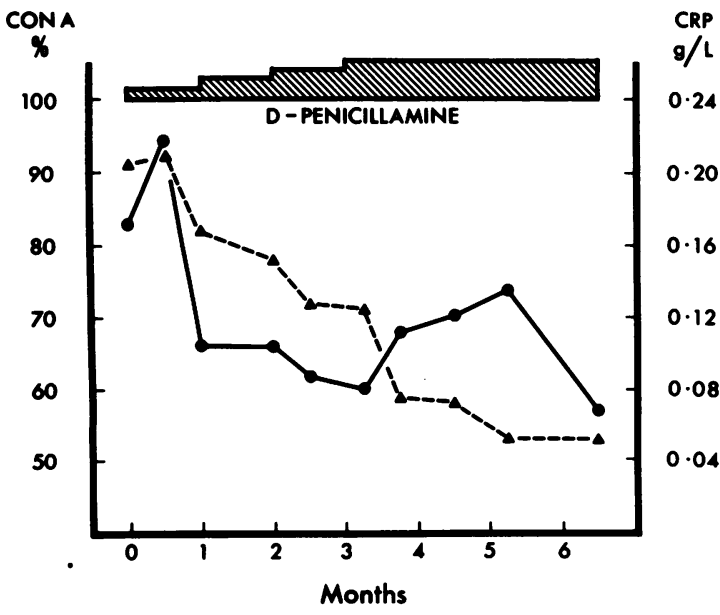

Fig. 2 Sequential changes in concanavalin- $A$ binding and $C R P$ levels in 1 patient on $D$-penicillamine treatment. are shown in Table 2. There was a significant improvement in pain score, Ritchie index, and early morning stiffness, indicating an overall satisfactory response to therapy. The changes in laboratory measurements are also shown in Table 2 and Fig. 2. There was a statistically significant increase in haemoglobin and a fall in blood viscosity. After 6 months there was also a significant fall in IgG and IgM levels and in rheumatoid factor titre, indicating that the change in disease status expected with penicillamine was achieved in this group of patients. There was also a significant fall in both con-A binding and CRP during the duration of the study (Fig. 2). However, as shown in Table 3 the correlation between con-A, CRP, and blood viscosity altered during the treatment period. In several patients con-A binding and CRP changed in different directions; this is reflected by the decreased correlation coefficient between the 2 measurements after 6 months' penicillamine therapy.

\section{Discussion}

The ability of con-A to give intense precipitation reactions with human serum proteins has been shown by Nakamura $e t$ al. ${ }^{7}$ using the Ouchterlony plate technique and by Harris and Robson ${ }^{8}$ using immunoelectrophoresis. More recent work has shown that con-A binds and precipitates serum glycoproteins, including haptoglobin, orosomucoid, $\alpha_{1}$-antitrypsin, $\alpha_{2}$-macroglobulin, transferrin, $\mathrm{C} 1$ esterase inhibitor, $\mathrm{C} 3, \mathrm{C} 4$, antichymotrypsin, and caeruloplasmin..$^{910}$ The interaction is similar to that of an antigenantibody reaction and therefore can be measured by any precipitin technique. ${ }^{11}$ As most of the glycoproteins mentioned are acute phase proteins, con-A binding provides a means of assessing acute phase protein responses. It is a simple, cheap, and easy measurement that can be carried out in a variety of ways on fresh and stored blood. The nephelometric estimation of con-A binding proteins has been previously shown to correlate well with changes in other acute phase proteins in a variety of diseases. ${ }^{1212}$ The present study was designed to investigate con-A binding as a measurement of acute phase reactants in rheumatoid arthritis, both as an index of disease activity at a single time point and as an assessment of response to drug therapy in a trial of D-penicillamine.

McConkey et al. $^{3}$ studied the use of serum acute phase proteins in a measurement of disease activity in RA. These authors have suggested that these proteins, and CRP in particular, are not only an important and useful index of inflammatory activity but also aid the prognosis of progressive destructive disease. Levels did not change on treatment with nonsteroidal anti-inflammatory drugs ${ }^{13}$ but are lowered during treatment with second line drug therapy, 
including gold, penicillamine, dapsone, and sulphinpyrazone. ${ }^{414}$ Changes in acute phase reactants may therefore be a useful measurement of drug responses in rheumatoid disease.

The results of the present study showed that con- $A$ binding is significantly higher in patients with rheumatoid arthritis than in normal persons, and there was a significant correlation between CRP and con-A binding in a cross-sectional study. This result was expected in view of the known ability of con-A to react with many of the acute phase reactants. Previous studies have also shown good correlations between con-A binding and other acute phase proteins in inflammatory diseases in man, including RA. ${ }^{12}$ Sequential studies of a range of acute phase proteins and of con-A binding were carried out to assess variation from week to week in the absence of alterations in treatment. These studies showed a good correlation between all measurements, and in a majority of the patients similar levels were recorded on each of the 6-week estimations, suggesting that con-A binding is providing a simple and reproducible measurement of the serum acute phase response in patients with RA.

The change in clinical and laboratory indices of disease activity in the 18 patients treated for 8 months with D-penicillamine showed the expected response with 'second line' drugs. The improvement in pain, joint tenderness, and morning stiffness was accompanied by improvement in haemoglobin, a drop in viscosity, and decrease in immunoglobulin and rheumatoid factor titres, as has been described previously with D-penicillamine. The clinical improvement was accompanied by significant decreases in con-A binding. The fall in CRP levels was similar to that reported by McConkey et al. on penicillamine therapy. ${ }^{4}$ However, changes in con-A binding and CRP did not always move in parallel; some patients showed improvement in CRP levels and not con-A, and vice-versa. This was reflected by a marked drop in the correlation coefficient between the 2 measurements after treatment with D-penicillamine. The numbers of patients in the study do not permit meaningful comparisons of individual subgroups of patients, and do not suggest that one estimation can be considered to be better than another. However, the results do suggest that the response to drugs such as D-penicillamine may be reflected by different changes in disease activity in different patients, and this might reflect a different final outcome of inflammation, joint damage, or extra-articular features of the disease. Long term follow-up studies of large numbers of patients are under way to investigate this further.

Con-A binding was shown to be an effective, reproducible measurement of the acute phase reac- tion in rheumatoid arthritis. It has the advantage of being a simple, cheap, and easy measurement that can be carried out on fresh and stored blood by a number of highly reproducible techniques, including nephelometry. The fact that changes in con-A do not always parallel those in CRP during treatment with penicillamine suggests that it may be a useful additional measurement to assess treatment responses and disease outcome in rheumatoid arthritis. Long term follow-up studies with con-A binding and CRP are recommended in the assessment of this disease, particularly in view of the possible correlation between acute phase responses and radiological progression. ${ }^{15}$

We are grateful to the Arthritis and Rheumatism Council for financial support and to Mrs M. Clarke for secretarial assistance.

\section{References}

${ }^{1}$ Warren C, Whicher J, Kohn J. The use of concanavalin A to measure acute phase proteins by laser nephelometry. J Immunol Methods 1980; 32: 141-50.

${ }^{2}$ Whicher J T, Warren C, Kohn J, Dieppe P, Read R. A nephelometric assay of concanavalin $\mathrm{A}$ binding proteins and its use in monitoring inflammatory disease. In: Protides in Biological Fluids 1979: 27.

${ }^{3}$ McConkey B, Crockson R A, Crockson A P. The assessment of rheumatoid arthritis: a study based on measurements of the serum acute-phase reactants. $Q J$ Med 1972; 41: 115-25.

4 McConkey B, Davies P, Crockson R A, et al. Effects of gold dapsone and prednisone on serum $\mathrm{C}$-reactive protein and haptoglobin and the erythrocyte sedimentation rate in rheumatoid arthritis. Ann Rheum Dis 1979; 38: 141-44.

${ }^{5}$ Ropes M W, Bennett G A, Cobb S, Jacox R, Jessar R A . Proposed diagnostic criteria for rheumatoid arthritis. Ann Rheum Dis 1957; 18: 49-53.

${ }^{6}$ Laurell C B. Quantitative estimation of proteins by electrophoresis in agarose gel containing antibodies. Anal Biochem 1966; 15: 45-52.

${ }^{7}$ Nakamura S, Tanaka K, Murabawa S. Specific protein of legumes which reacts with animal proteins. Nature 1960; 188: 144-5.

${ }^{8}$ Harris H, Robson E B. Precipitin reactions between extracts of Concanavalin enziformis (jack bean) and normal and pathogenic serum prote. Vox Sang 1963; 8: 348-55.

- Bog-Hansen T C, Bjerrum O J, Ramlau J. Detection of biospecific interaction during the first dimension electrophoresis in crossed immunoelectrophoresis. Scand J Immunol 1975; 4 (suppl 2): 141-7.

${ }^{10}$ Uhlenbruck G, Baldo B A, Steinhausen G, et al. Additional precipitation reactions of lectins with human serum glycoproteins. J Clin Chem Clin Biochem 1978; 16: 19-23.

${ }^{11}$ So Li, Goldstein I J. Protein-carbohydrate interaction. IV. Application of the quantitative precipitin method to polysaccharideconcanavalin A interaction. J Biol Chem 1967; 242: 1617-22.

${ }^{12}$ Kohn J M, Hernandez M, Riches P G. The value of acute phase reactants in the management of disease. Ricerca 1978; 8: suppl 1: 61-70.

${ }^{13}$ McConkey B, Crockson R A, Crockson A P, Wilkinson A R. The effects of some anti-inflammatory drugs on the acute phase proteins in rheumatoid arthritis. $Q J$ Med 1973; 42: 785-91.

${ }^{14}$ McConkey B, Amos R S, Durham S, Forster P J G, Hubball S, Walsh L. Sulphasalazine in rheumatoid arthritis. Br Med J 1980; i: 442-4.

${ }^{15}$ Amos R S, Constable T J, Crockson R A, Crockson A P, McConkey B. Rheumatoid arthritis: relation of serum C-reactive protein and ESR to radiographic change. $\mathrm{Br} \mathrm{Med} J \mathrm{1977}$; i: 195-7. 